\title{
ГЕОЕКОЛОГІЯ
}

\author{
УДК 550.424.6 \\ Ю. Ю. Войтюк", І. В. Кураєва*, Г. А. Кроїк**, С. П. Кармазиненко***, \\ О. В. Мацібора*** \\ * Інститут геохімії, мінералогї та рудоутворення ім. М. П. Семененка НАН України, \\ ** Дніпропетровський начіональний університет імені Олеся Гончара, \\ *** Інститут географії НАН України
}

\section{ВМІСТ ТА ФОРМИ ЗНАХОДЖЕННЯ ВАЖКИХ МЕТАЛІВ У ДОННИХ ВІДКЛАДАХ В ЗОНІ ВПЛИВУ ПРОМИСЛОВИХ ДЖЕРЕЛ ЗАБРУДНЕННЯ}

Встановлено закономірності розподілу важких металів та представлено результати вивчення форм знаходження $\mathrm{Zn}, \mathrm{Pb}, \mathrm{Cu}, \mathrm{Cr}$, Ni в донних відкладах у зоні впливу підприємств чорної металургії м. Маріуполя. Виконано еколого-геохімічну оцінку забруднення донних відкладів важкими металами.

Ключові слова: донні відклади, важкі метали, форми знаходження, техногенні геохімічні асоціації.

Установлены закономерности распределения тяжелых металлов и представлены результаты изучения форм нахождения $\mathrm{Zn}, \mathrm{Pb}, \mathrm{Cu}, \mathrm{Cr}, \mathrm{Ni}$ в донных отложениях в зоне влияния предприятий черной металлургии г. Мариуполя. Выполнена эколого-геохимическая оценка загрязнения донных отложений тяжелыми металлами.

Ключевые слова: донные отложения, тяжелые металы, формы нахождения, техногенные геохимические ассоциации.

Regularities in the distribution of heavy metals in sediments in the zone of influence of the steel industry in Mariupol are installed. The study results of the forms of occurrence of $\mathrm{Zn}, \mathrm{Pb}, \mathrm{Cu}, \mathrm{Cr}, \mathrm{Ni}$ are represented. Ecological and geochemical assessment of sediment contamination by heavy metals is performed.

Key words: sediment, heavy metal, forms of occurrence, manmade geochemical association.

Вступ. Одним 3 самих найрозповсюдженіших полютантів оточуючого середовища $є$ важкі метали. Основними джерелами забруднення донних відкладів $\epsilon$ аеральні викиди промислових підприємств, гідрогенне забруднення при надходженні промислових стічних вод у водойми, осад стічних вод, відвали золи, шлаку, руд, шламів, розливи нафти і сольових розчинів. В даний час знижується кількість публікацій $з$ аерального забруднення оточуючого середовища, у тому числі донних відкладів. При цьому підвищується увага до гідрогенного забруднення донних відкладів, водних джерел [3]. Гідрогенне забруднення донних відкладів може бути значним, забруднені відклади стають джерелом довгострокового забруднення води, навіть після припинення скидів у ріки неочищених стічних вод.

Слід відмітити, що в даний час оцінка екологічного стану донних відкладів по валовому вмісту важких металів $є$ малоінформативною, бо не відображає їх

(C) Ю. Ю. Войтюк, І. В. Кураєва, Г. А. Кроїк, С. П. Кармазиненко, О. В. Мацібора, 2014 
трансформацію і подальшу міграцію у суміжні середовища. Вивчення форм знаходження дає об'єктивну інформацію для еколого-геохімічної оцінки.

Донні відклади є активним накопичувачем важких металів. В силу цих причин вони сприяють самоочищенню водного середовища, що $€$ позитивним явищем функціонування водних систем. В той же час підвищується рівень забруднення донних відкладів, особливо у зонах екологічного ризику.

На сьогоднішній день донні відклади України та інші об'єкти навколишнього середовища забруднені різними хімічними речовинами. 3 низки численних забруднювачів пріоритетними вважаються важкі метали, техногенне накопичення яких в навколишньому середовищі йде високими темпами. До найбільш проблемних в цьому плані відноситься територія міста Маріуполь Донецької області, де найбільшими забруднювачами оточуючого середовища є два великих підприємства чорної металургії - ПАТ «Маріупольський металургійний комбінат імені Ілліча», ПАТ «Металургійний комбінат «Азовсталь». Їх діяльність призводить до зміни природних геохімічних особливостей донних відкладів, які акумулюють різні елементи скидів та викидів цих підприємств.

Значна кількість важких металів сорбується донними відкладами, тому вони можуть розглядатися як індикатор забруднення навколишнього природного середовища, у тому числі якості вод, що і визначає актуальність проведення даного дослідження.

Місто Маріуполь $є$ унікальним для вивчення геохімічних особливостей донних відкладів під впливом техногенезу, тому що в даному випадку є можливість дослідження як річкових (р. Кальміус, р. Кальчик), так і морських донних відкладів (прибережна частина Азовського моря).

Мета роботи - встановлення вмісту та форм знаходження важких металів у донних відкладах р. Кальміус, р. Кальчик та прибережній частині Азовського моря (м. Маріуполь).

Методи досліджень. Опробування донних відкладів проведено відповідно до вимог ГОСТ 17.1.5.01-80, ГОСТ Р 51592-2000 [2, 8]. Концентрації хімічних елементів у пробах визначено за допомогою атомно-емісійного спектрального методу на СТЕ-1 спектрографі великої дисперсії [9].

Для характеристики забруднення донних відкладів використано коефіцієнт концентрації $(K c)$ і сумарний показник забруднення $(Z c)[5]$ :

$$
\begin{gathered}
Z c=\sum_{1}^{n} K c-\mathbf{6 - 1}, \\
K c=\frac{C i}{C \phi},
\end{gathered}
$$

де $\mathrm{C} i$ - вміст хімічного елементу в оцінюваному об'єкті, С $\phi$ - фоновий вміст хімічного елементу, $n$ - число хімічних елементів, що входять в асоціацію, що вивчається.

Вивчення форм знаходження важких металів у донних відкладах виконано методом послідовних витяжок (рис. 1). Концентрації важких металів у витяжках визначено методом атомно-абсорбційного аналізу на спектрометрі КАС-115. 


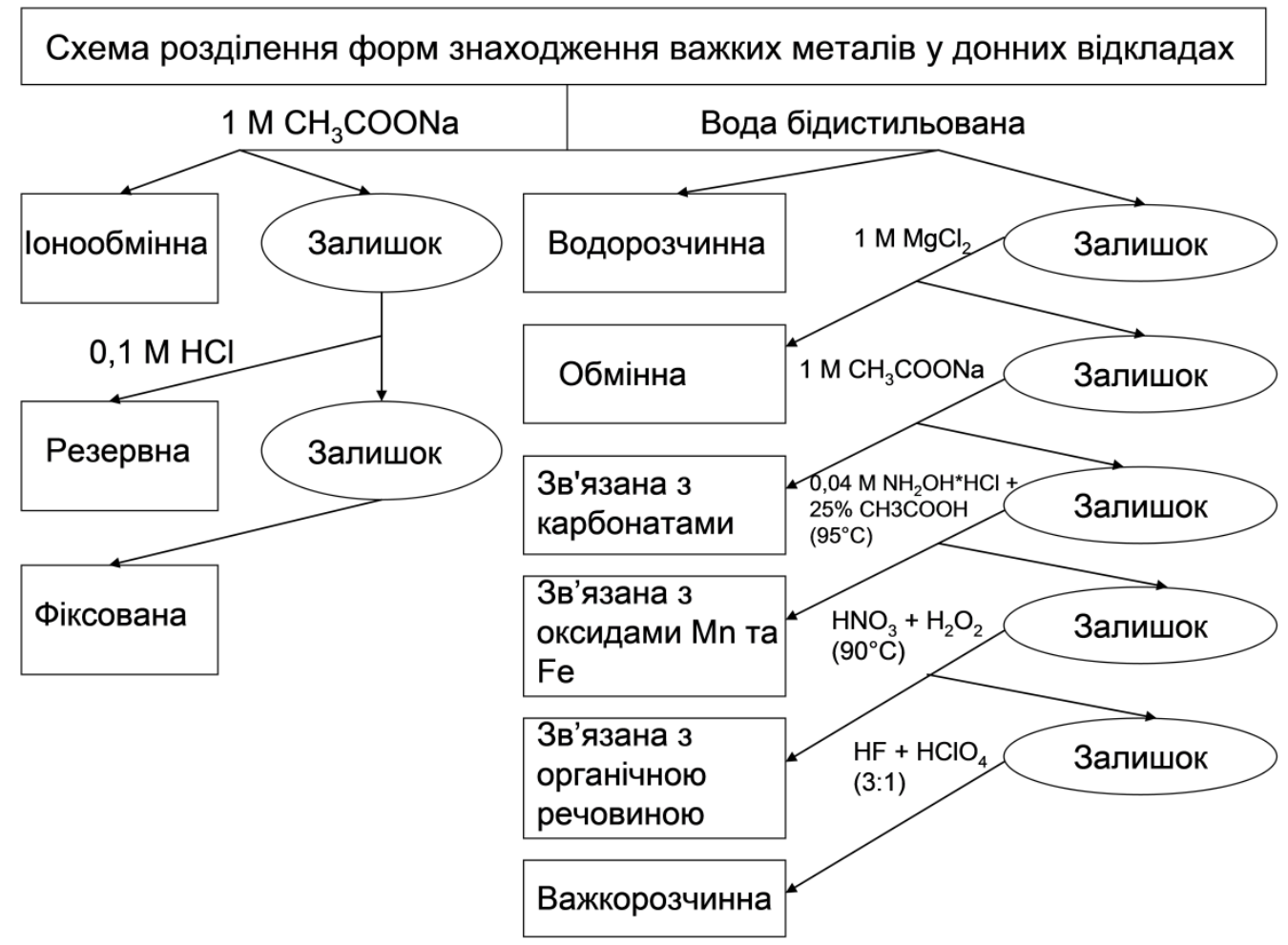

Рис. 1. Схема розділення форм знаходження важких металів

\section{Викладення основного матеріалу}

Попередні дослідження авторів 3 оцінки еколого-геохімічного стану об'єктів довкілля (грунтів, грунтової мікобіоти та рослинності) м. Маріуполя $[4,6]$ дозволили зробити висновок про несприятливі умови проживання місцевого населення. На території міста виявлено райони з максимальним поліелементним забрудненням грунтів, визначено техногенні геохімічні асоціації важких металів у грунтах під впливом підприємств чорної металургії, визначено форми знаходження важких металів у грунтах та геохімічні бар'єри їх концентрації.

Для комплексного геохімічного підходу при оцінці стану об'єктів довкілля у даній статті особливу увагу було приділено донним відкладам району досліджень.

Визначено вміст важких металів у донних відкладах р. Кальміус, р. Кальчик і прибережної частини Азовського моря на техногенних та фонових ділянках (табл. 1). Встановлено, що для низки елементів характерне перевищення їх вмісту у донних відкладах над фоновими значеннями, що зумовлено, найвірогідніше, їх техногенним походженням. Розраховано коефіцієнти концентрації важких металів у донних відкладах та виділено їх техногенні геохімічні асоціації: $\mathrm{Mn}_{7,7}>\mathrm{Zn}_{7,5}>\mathrm{V}_{6}$ $>\mathrm{Cr}_{5,6}>\mathrm{Cu}_{4,5}$ (р. Кальміус), $\mathrm{Pb}_{10}>\mathrm{Cr}_{8,3}>\mathrm{Mn}_{4,8}>\mathrm{Cu}_{4,5}>\mathrm{Zn}_{4}$ (р. Кальчик), $\mathrm{Pb}_{11,3}>$ $\mathrm{Zn}_{5,5}>\mathrm{Mo}_{4}>\mathrm{V}_{3,8}>\mathrm{Cu}_{3,1}$ (прибережна частина Азовського моря).

Сумарний показник забруднення донних відкладів р. Кальміус змінюється від 14 до 115, при середньому значенні 42. Для донних відкладів р. Кальчик сумарний показник забруднення становить 44-79, при середньому значенні 56. Для морських донних відкладів сумарний показник забруднення змінюється від 3 до 76, при середньому значенні 37 . За середнім значенням сумарного показника рівень 
забруднення донних відкладів досліджених об'єктів оцінено як високий. Забруднення донних відкладів р. Кальміус у деяких точках досягає дуже високого рівня.

Таблиия 1

Валовий вміст важких металів у донних відкладах м. Маріуполя, мг/кг

\begin{tabular}{|c|c|c|c|c|c|c|c|c|c|c|c|}
\hline \multirow{2}{*}{ 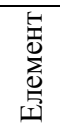 } & \multicolumn{3}{|c|}{$\begin{array}{l}\text { p. Кальміус } \\
(\mathrm{n}=63)\end{array}$} & \multicolumn{3}{|c|}{$\begin{array}{c}\text { p. Кальчик } \\
(\mathrm{n}=36)\end{array}$} & \multirow{2}{*}{$\begin{array}{c}\text { Фонове } \\
\text { значен- } \\
\text { ня }\end{array}$} & \multicolumn{3}{|c|}{$\begin{array}{c}\text { Азовське море } \\
(\mathrm{n}=36)\end{array}$} & \multirow{2}{*}{$\begin{array}{c}\text { Фонове } \\
\text { значен- } \\
\text { ня }\end{array}$} \\
\hline & Min & $\operatorname{Max}$ & Med & Min & Max & Med & & Min & $\operatorname{Max}$ & Med & \\
\hline $\mathrm{Mn}$ & 400 & 10000 & 3850 & 1000 & 4000 & 2375 & 500 & 300 & 2000 & 1050 & 500 \\
\hline $\mathrm{Ni}$ & 40 & 200 & 83 & 30 & 80 & 68 & 20 & 2 & 70 & 32 & 20 \\
\hline $\mathrm{Co}$ & 5 & 20 & 10 & 4 & 8 & 6 & 10 & 2 & 30 & 10 & 5 \\
\hline $\mathrm{V}$ & 70 & 250 & 120 & 60 & 80 & 70 & 20 & 10 & 200 & 75 & 20 \\
\hline $\mathrm{Cr}$ & 80 & 1000 & 280 & 100 & 1000 & 413 & 50 & 10 & 700 & 238 & 100 \\
\hline Mo & 1 & 10 & 4 & 2 & 4 & 3 & 2 & 3 & 20 & 8 & 2 \\
\hline $\mathrm{Cu}$ & 30 & 200 & 67 & 50 & 80 & 68 & 15 & 6 & 100 & 46 & 15 \\
\hline $\mathrm{Pb}$ & 30 & 100 & 67 & 100 & 300 & 200 & 20 & 30 & 300 & 170 & 15 \\
\hline $\mathrm{Zn}$ & 100 & 2000 & 525 & 100 & 300 & 280 & 70 & 100 & 500 & 275 & 50 \\
\hline Sn & 2 & 40 & 8 & 4 & 8 & 6 & 2 & 2 & 10 & 6 & 2 \\
\hline
\end{tabular}

Примітка. Min - мінімальне значення, Max - максимальне, $M e d$ - середнє, $\mathrm{n}$ - кількість проб.

Дослідження просторового розподілу коефіцієнтів концентрації важких металів у донних відкладах (рис. 2) показало, що підвищеними їх значеннями у поверхневих шарах донних відкладів серед досліджених об'єктів характеризується р. Кальчик.

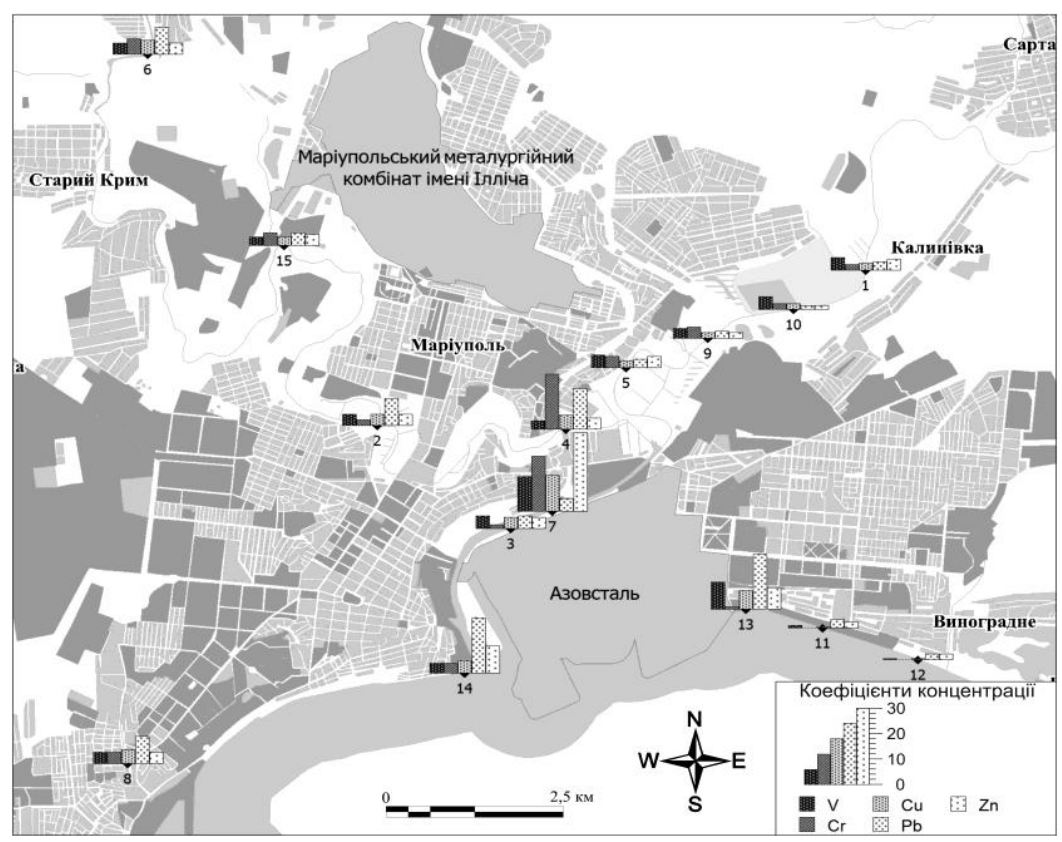

Рис. 2. Схема розподілу коефіціснтів концентрації важких металів у донних відкладах м. Маріуполя (1-15 - ділянки відбору зразків)

Концентрації важких металів у донних відкладах р. Кальміус коливаються у широкому діапазоні. Найбільші їх значення спостерігаються у місцях скиду стічних 
вод ПАТ «Металургійний комбінат «Азовсталь» у р. Кальміус. Наприклад, коефіцієнт концентрації $\mathrm{Zn}$ досягає $30, \mathrm{Cr}-20, \mathrm{Cu}-13$.

Донні відклади прибережної частини Азовського моря, що розташовані у південно-східній частині міста, характеризуються найменшими коефіцієнтами концентрації важких металів.

Аналіз розподілу коефіцієнтів концентрації важких металів у донних відкладах показав, що важкі метали концентруються здебільшого у місцях скиду стічних вод та акумуляції аеральних викидів промислових підприємств.

В даний час у науковій літературі значна увага приділяється вивченню форм знаходження хімічних елементів, особливо рухомим формам, які характеризують подальшу їх міграцію у суміжні середовища. Тому було виконано значний об'єм експериментально-методичних робіт по визначенню форм знаходження важких металів із застосуванням різних екстрагентів.

Досліджено розподіл форм знаходження важких металів у річкових та морських донних відкладах зон впливу підприємств чорної металургії.

За допомогою неселективних екстрагентів визначено іонообмінну (ацетатноамонійний буфер $(\mathrm{pH} 4,8))$, резервну $(1 \mathrm{M} \mathrm{HCl})$ та фіксовану форми знаходження ВМ (визначалася з розрахунку залишок після всіх екстракцій).

Встановлено, що частка важких металів у іонообмінній формі у донних відкладах поблизу підприємств чорної металургії зменшується в ряду (\%): у річкових відкладах $-\mathrm{Zn}(11,4)>\mathrm{Pb}(7)>\mathrm{Ni}(4)>\mathrm{Cr}(1,8)>\mathrm{Cu}(0,9)$; у морських відкладах $-\mathrm{Zn}(13,7)>\mathrm{Pb}(5,7)>\mathrm{Ni}(4,4)>\mathrm{Cr}(3)>\mathrm{Cu}(1,2)$.

Частка важких металів у резервній формі у донних відкладах зменшується в ряду (\%): у річкових відкладах $-\mathrm{Pb}(61)>\mathrm{Cu}(53)>\mathrm{Zn}(27,5)>\mathrm{Ni}(20)>\mathrm{Cr}(10,3) ;$ у морських відкладах - $\mathrm{Cr}(57,6)>\mathrm{Pb}(44,3)>\mathrm{Cu}(41,7)>\mathrm{Zn}(33,3)>\mathrm{Ni}(21,5)$.

Частка важких металів у фіксованій формі у донних відкладах зменшується в ряду: річкові відклади $-\mathrm{Cr}(87,9)>\mathrm{Ni}(76)>\mathrm{Zn}(61)>\mathrm{Cu}(47,7)>\mathrm{Pb}(31,7) ;$ морські відклади - $\mathrm{Ni}(74)>\mathrm{Cu}(57)>\mathrm{Zn}(52,9)>\mathrm{Pb}(50)>\mathrm{Cr}(39,4)$.

Таким чином, еколого-геохімічна небезпека забруднення донних відкладів, що оцінена по вмісту іонообмінних форм важких металів [1], відповідає напруженій екологічній ситуації.

За допомогою селективних екстрагентів [11] виділено форми знаходження важких металів у донних відкладах р. Кальміус у зоні впливу підприємств чорної металургії м. Маріуполя та на фонових ділянках (табл. 2).

Форми знаходження важких металів у донних відкладах р. Кальміус

\begin{tabular}{|c|c|c|c|c|c|c|c|}
\hline \multirow{2}{*}{ Елемент } & \multirow{2}{*}{$\begin{array}{c}\text { Валовий } \\
\text { вміст, } \\
\text { мг/кг }\end{array}$} & \multicolumn{6}{|c|}{ Форми знаходження, \% } \\
\hline & & 1 & 2 & 3 & 4 & 5 & 6 \\
\hline \multirow{2}{*}{$\mathrm{Cu}$} & 200 & 0,05 & 0,8 & 14,2 & 40 & 20 & 25 \\
\hline & $\overline{15}$ & $\overline{0,01}$ & $\overline{0,2}$ & $\overline{18}$ & $\overline{20}$ & $\overline{10}$ & 52 \\
\hline \multirow{2}{*}{$\mathrm{Zn}$} & 620 & 0,1 & 10 & 12 & 40 & 18 & 20 \\
\hline & $\overline{70}$ & $\overline{0,02}$ & $\overline{2}$ & $\overline{15}$ & $\overline{22}$ & $\overline{10}$ & $\overline{51}$ \\
\hline \multirow{2}{*}{$\mathrm{Pb}$} & 360 & 0,01 & 8 & 10 & 42 & 18 & 22 \\
\hline & 20 & $\overline{0,005}$ & $\overline{2}$ & $\overline{19}$ & $\overline{24}$ & $\overline{9}$ & $\overline{46}$ \\
\hline
\end{tabular}

Примітка. Форми знаходження: 1 - водорозчинна, 2 - обмінна, 3 - зв'язана 3 карбонатами, 4 - зв'язана 3 оксидами $\mathrm{Mn}$ та Fe, 5 - зв'язана 3 органічною речовиною, 6 - важкорозчинна. 
У чисельнику - значення для донних відкладів зон впливу підприємств чорної металургії, у знаменнику - на фоновій ділянці.

На техногенно забруднених ділянках найменша кількість важких металів міститься у водорозчинній формі $(0,05-0,1 \%)$. Слід відмітити, що попри дуже високий рівень забруднення донних відкладів (валовий вміст важких металів значно вищий від відповідного фонового значення), вміст хімічних елементів у водній витяжці залишається доволі низьким.

Для техногенно забруднених донних відкладів вміст важких металів в обмінній формі коливається у широкому діапазоні і становить $0,8-10 \%$. Кількість важких металів, сполучених з карбонатами - 10-11,2\%.

Основною формою знаходження важких металів у техногенно забруднених донних відкладах р. Кальміус є форма сполук з оксидами $\mathrm{Mn}$ та Fe. Частка цієї форми становить - 40-42\%. Значна частка форм важких металів, зв'язаних 3 органічними речовинами донних відкладів - 18-20\%. У досліджених донних відкладах 20-25 \% важких металів знаходяться у складі геохімічно інертних літогенних форм. Для фонових ділянок ця величина становить -46-52\%.

Висновки. За геохімічними критеріями (коефіцієнт концентрації, сумарний показник забруднення) встановлено, що усі досліджені об'єкти характеризуються високим рівнем забруднення.

Техногенне забруднення донних відкладів м. Маріуполь призвело до порушення природного співвідношення форм знаходження важких металів. В досліджених донних відкладах підвищується вміст іонообмінних форм важких металів, що сприяє їх міграції у водне середовище.

Результати досліджень визначають необхідність розробки науково обгрунтованої системи заходів по поліпшенню екологічної ситуації.

\section{Бібліографічні посилання}

1. Андросова Н. К. Геолого-экологические исследования и картографирование (Геоэкологическое картирование): учебное пособие / Н. К. Андросова - М.: Издательство Российского университета дружбы народов, 2000. -98 c.

2. Вода. Общие требования к отбору проб: Государственный стандарт РФ ГОСТ Р 51592-2000 (принят и введен в действие постановлением Госстандарта РФ от 21 апреля 2000 г. N 117-ст.). [Дата введения 1 июля 2001 г.] - М.: Изд-во Госстандарт, 2000. - $12 \mathrm{c.}$

3. Водяницкий Ю. Н. Влияние техногенных и природных факторов на содержание тяжелых металлов в почвах среднего Предуралья / Ю. Н. Водяницкий, А. А. Васильев // Почвоведение. - 2010. - № 9. - С. 1089-1099.

4. Войтюк Ю. Ю. Вплив діяльності підприємств чорної металургії на вміст і форми знаходження важких металів у об'єктах навколишнього середовища / Ю. Ю. Войтюк， І.В.Кураєва， А.І.Самчук， В. Й. Маничев // Мінералогічний журнал. - К., 2011. - № 3. - С. 77-83. $325 \mathrm{c}$.

5. Геохимия окружающей среды / [ Сает Ю. Е. [и др.]. - М.: Недра, 1990. -

6. Кураєва І. В. Оцінка впливу діяльності підприємств чорної металургії на оточуюче середовище за геохімічними показниками (на прикладі м. Маріуполя) / І. В. Кураєва, Ю. Ю. Войтюк, В. Й. Манічев // Еколого-геохімічні дослідження об’єктів довкілля України. - К.: «Альфа Реклама», 2012. - Розд. 3.2. - С. 104-119. 
7. Митропольський О. Ю. Екогеохімія Чорного моря / О. Ю. Митропольський, Є. І. Насєдкін, Н. П. Осокіна. - К., 2006. - 279 с.

8. Охрана природы. Гидросфера. Общие требования к отбору проб донных отложений для анализа на загрязненность: ГОСТ 17.1.5.01-80. - [действующий от 1982-01-01]. - М.: Госстандарт СССР, 1980. - 5 с.

9. Русанов А. К. Основы количественного спектрального анализа руд и минералов / А. К. Русанов. - М.: Недра, 1971. - 360 с.

10. Техногенно-экологическая безопасность биогеосистемы Бугского лимана в условиях загрязнения тяжелыми металлами / [Долин В. В., Смирнов В. Н., Ищук А. А., Орлов А. А.]. - Киев-Николаев: РАЛ-поліграфія, 2011. - 200 с.

11. Физико-химические условия образования мобильных форм токсичных металлов в почвах / [Самчук А. И. [и др.] // Минералогический журнал. - К., 1998. № 2. - C. $48-59$.

Надійшла до редколегії 21.03.2014 p. 